\title{
人工肛門造設患者の生活の主観的評価に 関連する因子の構造と影響要因
}

\author{
高見沢恵美子 $*$, 佐藤禮子 $* *$ \\ Structure and factor that influence ostomate's \\ subjective postoperatively attitudes \\ Emiko Takamizawa \\ Doctoral Student, School of Nursing, Chiba University. \\ Reiko Sato \\ School of Nursing, Chiba University.
}

\begin{abstract}
The purpose of this research is to clarify the structure of the quality of life of the ostomate and to clarify the factors that influence the structure. Knowledge the structure of the quality of life will help nurses to enhance ostomates's attitudes about themselve after discharge from the hospital.

Causal relations of ten factors are clarified by accepting significant path coefficients using the Covariance Structure Analysis in 159 ostomates. The ten factors are (1) discouragement with having a stoma, (2) relief due to effectiveness of stoma surgery, (3) positive attitude toward life, (4) subjective attitudes about life, (5) personal assessment of health, (6) difficulties with living, (7) burden of having a stoma, (8) satisfaction with diet, (9) self-esteem, and (10) social support. The structure of the ostomate's quality of life is gained by displaying each causal relationship.

The factors that influence the structure are (1) marital status, (2)Independence in changing of a stoma appliance, and (3) sexual satisfaction. These factors are related to the family.
\end{abstract}

\footnotetext{
* 千葉大学大学院看護学研究科博士後期課程 $* *$ 千葉大学看護学部
} 


\section{要旨}

人工肛門造設患者の退院後の主観的評価を高めていくために，人工肛門造設患者のQOLモデルを 作成し，さらにモデルを構成する因子に関連する要因を明かにした。

共分散構造分析を行い，有意なパス係数のみで構成した結果，人工肛門造設術の落胆，人工肛門 造設術の安堵感, 積極的生活姿勢, 生活の主観的評価, 健康的生活, 生活上の苦痛, 人工肛門の負 担感，食事の満足，自己価值観，ソーシャルサポートの10因子の因果関係が明かになった。

モデルを構成する 10 因子に影響を及ぼしていた要因は，婚姻状況，人工肛門装具交換の分担，性 生活の満足であり，いずれも家族が関係する 3 要因であった。

\section{I .はじめに}

人工肛門造設患者のQuality of Life(以下 QOL)に関する測定用具の作成および信頼性と 妥当性を検討した先行研究1)では，人工肛門造 設患者の日常生活行動，人工肛門造設術の手術 観，及び積極的生活姿勢が日本人人工肛門造設 患者に適用できる主観的なQOLの測定用具で あると考えられた。

人工肛門造設患者の生活の主観的評価に関連 する要因は，いまだ明らかになっていない。 人工肛門造設患者の退院後の生活の主観的評価 を高める看護介入を検討するためには, 退院後 の生活で患者が感じている主観的内容を理解し, 主観に変化をもたらす要因を予測できる展望が 必要である。

本研究の目的は, 人工肛門造設患者の生活の 主観的評価に関連する因子の構造を明らかにし, 生活の主観的評価に影響する要因を検討するこ とである。

\section{II. 文献検討}

Burckhardt ${ }^{2)}$ は, Lazarus ら ${ }^{3)}$ 枠組みを使 い，主観的評価に基づいたQOLを測定した。そ の結果，関節炎患者のQOLには，自己価値観， 知覚されたソーシャルサポート, ヘルスローカ スオブコントロール, 病気に対する否定的態度 の少なさのような認識的要因が直接影響し, 疼 痛または障害のような要因は，それらの認識的 要因を介してQOLの変化に間接的に影響して いることを明らかにした。

Muhlenkampら ${ }^{4)}$ は, 自己価値観, ソーシャル サポート，およびヘルスローカスオブコントロ
ールは，健康のためのセルフケアの実行に寄与 していることを，一般人を対象にし証明した。 また, Linnら5)は, インターナルコントロール が，QOLの高い評価に正の影響力を持っている ことを明らかにした。

人工肛門造設術を受けた患者のQOLに影響 する要因は，いまだ明らかにされていない。し かし，以上のQuality of Lifeに影響する要因の 文献検討は，人工肛門造設患者のQOLに，自己 価值観, 知覚されたサポート, ヘルスローカス オブコントロール，人工肛門造設術への認識, 健康のためのセルフケアが影響していることを 予測させるものである。

\section{III. 研究方法}

対象は, Y病院, および関連U病院に通院して いる人工肛門造設患者で, 研究承諾の得られた 91名, 東京都内の患者会参加者で, 研究承諾の 得られた68名, 計159名である。

研究方法は, 自己報告式質問紙調査で, 外来 通院患者に対しては病歴調査もあわせて行った。 質問紙調査の内容は，人工肛門造設患者の日常 生活行動 ${ }^{1)}$, 人工肛門造設術の手術観 ${ }^{1)}$, 積極的 生活姿勢1), 宗像のソーシャルサポート尺度6)7, 自己価值観尺度7)8 , 渡辺のヘルスローカスオブ コントロール尺度9)，および人工肛門造設患者 の研究1011112113) とQOLの研究7144を参考にし作 成した，ストマケアに関する要因，身体的要因， ならびに社会的要因である。ストマケアに関す る要因は, 人工肛門装具の交換の分担, 患者が 理解している病名, 術前の人工肛門造設術実施 についての説明の有無等である。身体的要因は， 術後経過年月, 排尿障害の有無, 性機能等であ 
る。社会的要因は, 婚姻状況, 昨年1年間の収

入，就業状況等である。

病歴調査内容は, 人工肛門造設術についての 研究1511617)を参考にし作成した, 病名, 術式, 直 腸癌のステージ, 既往歴等の, 治療的要因であ る。

分析は, 東京大学大型計算機センターのSAS ver5.18を使用し, 共分散構造分析は, 早稲田大 学情報科学教育研究センターのSAS ver6.04を 使用した。

\section{IV.結 果}

対象159名の内訳は, 男性100名(62.8\%), 女 性 59 名 $(37.2 \%)$, 平均年齢 63.4 歳( $\mathrm{SD}=9.6)$, 平 均術後経過年数は， 5.1 年 $(\mathrm{SD}=5.3)$ であった。

\section{1. 生活の主観的評価に関連する因子の構造} 人工肛門造設術の手術観, 積極的生活姿勢, 日常生活行動, ソーシャルサポート, 自己価値 観, ヘルスローカスオブコントロールの6尺度計 11因子を用いて，主観的評価に関連する因子の 構造を分析した。構成概念間の因果関係を, 測 定誤差を考慮し明らかにするために, 各因子の 信頼係数から誤差変数の分散をもとめ, 誤差分 散を固定母数とし共分散構造分析を行った。観 測変数間の相関行列は表1に示した。へルスロー カスオブコントロールは, 観測変数間の相関係 数が低く，共分散構造分析の結果有意なパス係 数が得られなかった。T検定で危険率 $5 \%$ 以下で 有意だったパス係数だけで構成した結果，10因 子の因果関係が明らかになった。これらのパス

図 I Causal relations that influence Subjective attitudes about life

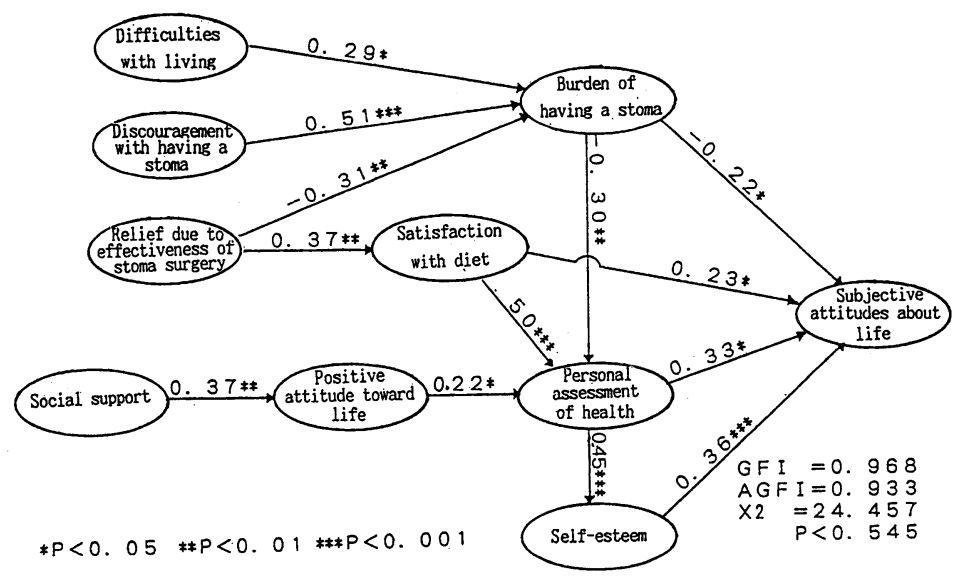

表 I Correlation coefficients

Positive attitude toward life

Subjective attitudes about life

Personal assessment of health

Difficulties with living

Burden of having a stoma

Satisfaction with diet

Discouragement with having a stoma

Relief due to effectiveness of stoma surgery

Social support

Self-esteem

Health locus of control
1.00

.221 .00

$.21 \quad .501 .00$

$.01-.09-.141 .00$

$-.06-.34-.25-.241 .00$

$\begin{array}{llllll}.12 & .41 & .35 & .03 & -.09 & 1.00\end{array}$

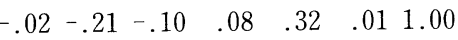

$\begin{array}{llllllll}.15 & .29 & .17 & -.14 & -.15 & .23 & .23 & 1.00\end{array}$

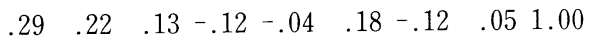

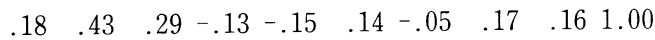

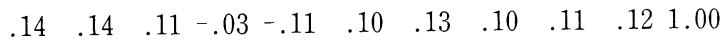


表 2 Factors that influence ostomate's subjective quality of life

\begin{tabular}{|l|l|l|l|}
\hline & $\begin{array}{l}\text { Marital } \\
\text { status }\end{array}$ & $\begin{array}{l}\text { Sexual } \\
\text { satisfaction }\end{array}$ & $\begin{array}{l}\text { Sharing the changing } \\
\text { of a stoma appliance }\end{array}$ \\
\hline $\begin{array}{l}\text { Burden of having } \\
\text { a stoma }\end{array}$ & $\mathrm{F}=3.15 *$ & & $\mathrm{~F}=3.36 *$ \\
\hline $\begin{array}{l}\text { Social support } \\
\text { ment of health }\end{array}$ & $\mathrm{F}=3.95 *$ & $\mathrm{~F}=8.02 * *$ \\
\hline $\begin{array}{l}\text { Subjective atti- } \\
\text { tudes about life }\end{array}$ & $\mathrm{F}=3.65 *$ & $* \mathrm{P}<0.05, * * \mathrm{P}<0.001$ \\
\hline
\end{tabular}

表 3 Least squares mean and standarised deviation of Burden of having a stoma by Marital status

\begin{tabular}{|l|c|c|c|}
\hline $\begin{array}{l}\text { Marital } \\
\text { status }\end{array}$ & $\begin{array}{l}\text { Least squares } \\
\text { mean }\end{array}$ & $\begin{array}{l}\text { standarised } \\
\text { deviation }\end{array}$ & $\begin{array}{l}\text { Multiple } \\
\text { comparison }\end{array}$ \\
\hline Marrid & 10.30 & 0.28 & \multirow{2}{*}{$* 5$} \\
\hline Divorced & 11.00 & 0.65 & \\
\hline Widowed & 8.18 & 1.79 \\
\hline Unmarried & 11.00 & & \\
\hline
\end{tabular}

表 4 Least squares mean and standarised deviation of Social support by Independence in changing of a stoma appliance

\begin{tabular}{|l|c|c|c|}
\hline $\begin{array}{l}\text { Independence in changing } \\
\text { of a stoma appliance }\end{array}$ & $\begin{array}{l}\text { Least squares } \\
\text { mean }\end{array}$ & $\begin{array}{l}\text { Standarised } \\
\text { deviation }\end{array}$ & $\begin{array}{l}\text { Multiple } \\
\text { comparison }\end{array}$ \\
\hline Independently & 8.52 & 0.18 \\
\hline Assisted by the family & 9.64 & 0.57 \\
\hline $\begin{array}{l}\text { Complete dependence of } \\
\text { the family }\end{array}$ & 7.33 & 0.71 & \\
\hline
\end{tabular}


表 5 Least squares mean and standarised deviation of Social support by Sexual satisfaction

\begin{tabular}{|l|c|c|l|}
\hline $\begin{array}{l}\text { Sexual } \\
\text { satisfaction }\end{array}$ & $\begin{array}{l}\text { Least squares } \\
\text { mean }\end{array}$ & $\begin{array}{l}\text { Standarised } \\
\text { deviation }\end{array}$ & $\begin{array}{l}\text { Multiple } \\
\text { comparison }\end{array}$ \\
\hline Satisfaction & 9.33 & 0.88 & \multirow{2}{*}{$*$} \\
\hline Unsatisfied & 8.87 & 0.24 & \\
\hline $\begin{array}{l}\text { No sexual } \\
\text { activity }\end{array}$ & 7.90 & 0.27 & \\
\hline
\end{tabular}

表 6 Least squares mean and standarised deviation of Personal assesment of health by Sexual satisfaction

\begin{tabular}{|l|c|c|c|}
\hline $\begin{array}{l}\text { Sexual } \\
\text { satisfaction }\end{array}$ & $\begin{array}{l}\text { Least squares } \\
\text { mean }\end{array}$ & $\begin{array}{l}\text { Standarised } \\
\text { deviation }\end{array}$ & \multicolumn{1}{|c|}{$\begin{array}{l}\text { Multiple } \\
\text { comparison }\end{array}$} \\
\hline Satisfaction & 21.50 & 1.26 & $*$ \\
\hline Unsatisfied & 16.31 & 0.36 & $*$ \\
\hline $\begin{array}{l}\text { No sexual } \\
\text { activity }\end{array}$ & 17.05 & 0.40 & \\
\hline
\end{tabular}

表 7 Least squares mean and standarised deviation of Subjective attitudes about life by Sexual satisfaction

\begin{tabular}{|l|c|c|c|}
\hline $\begin{array}{l}\text { Sexual } \\
\text { satisfaction }\end{array}$ & $\begin{array}{l}\text { Least squares } \\
\text { mean }\end{array}$ & $\begin{array}{l}\text { Standarised } \\
\text { deviation }\end{array}$ & $\begin{array}{l}\text { Multiple } \\
\text { comparison }\end{array}$ \\
\hline Satisfaction & 15.17 & 1.09 & $*$ \\
\hline Unsatisfied & 12.29 & 0.30 & \\
\hline $\begin{array}{l}\text { No sexual } \\
\text { activity }\end{array}$ & 12.89 & 0.34 & \\
\hline
\end{tabular}


係数と因果関係は，図1に示すとうりであった。 生活の主観的評価の決定係数は，0.67であった。 因果モデルの説明力の目安となる Goodnes of Fit Index(GFI)は0.968, Adjusted GFI(AGFI) は0.933と高い值で, 因果モデルのデータの説明 力と予測力は高かく, $\mathrm{X}^{2}$ 検定は有意差がなく, モデルがデータと適合していると言えた。

\section{2.構造モデルに影響する要因}

因果モデルを構成していた10因子を従属変数 にし，ストマケアに関する要因，身体的要因， 社会的要因, および治療的要因を独立変数とし て, 多重比較にScheffe法を用い, 一元配置分散 分析を行った。F検定およびSheffe法による多 重比較が,それぞれ危険率5\%以下で有意差が認 められた要因を採用した。因果モデルに影響す る要因は，婚姻状況，人工肛門装具交換の分担， 性生活の満足であり，いずれも家族が関係する 3要因であった(表2)。

婚姻状況は, 既婚で配偶者が健在な群が, 配 偶者と死別した群より人工肛門の負担感を強く 感じていた(表3)。

人工肛門装具交換の分担は，家族が人工肛門 装具交換を一部手伝っている群が，家族がすべ て行っている群よりソーシャルサポートを強く 感じていた(表4)。

性生活の満足は, 性生活について術前と同じ くらい満足している群が, 手術前から性生活の ない群よりソーシャルサポートを強く感じてい た(表5)。

性生活に術前と同じくらい満足している群は, 手術前に比べ不満足である群および手術前から 性生活がない群より健康的生活を強く感じてい た(表6)。

また, 性生活に手術前と同じくらい満足して いる群は, 手術前にくらべ不満足である群より 生活の主観的評価が高くなっていた(表7)。

\section{V.考 察}

\section{1. 生活の主観的評価に関連する因子の構造}

図1に示したモデルは, 平均年齢63.4歳 $(\mathrm{SD}=$ 9.6)の人工肛門造設患者に一般化できるモデル であると考える。
生活の主観的評価は, 人工肛門の負担観によ って低下し, 人工肛門の負担感が大きいことは, 健康的生活の実感を持ちにくくし，同時に生活 の主観的評価を下げると言える。患者が生活の 主観的評価を高く持つためには, 人工肛門の負 担感が低く, 食事の満足感が得られ, 健康的生 活を実感し，自己価值観を高く感じられること が必要であると考える。

Stanwyck ${ }^{18)}$ にれね゙，成人の自己価值観は， 社会的関係と経験の発達をおもに反映している と考えられている。Lewis ${ }^{19}$, Padillaら ${ }^{20)}$, およ びYoungら ${ }^{21)}$ の研究は, 癌患者执よび悪性黒色 腫の患者のQOLに，自己価值観，および自己有 用性が重要であることを指摘している。慢性疾 患の患者が評価したQOLには，低い自己価值

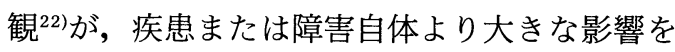
与えていることが報告されている。本研究でも， 自己価值観が最も強く生活の主観的評価に影響 していた。

人工肛門の負担感には, 手術観が大きく影響 し，人工肛門造設術の落胆が少なく，人工肛門 造設術の安堵感が大きいことが重要であり, 痛 みや日常生活の支障などの生活上の苦痛が，少 ないことが人工肛門の負担感の軽減につながる と言える。また，人工肛門造設術の安堵感が大 きいことは，食事の満足を高めており，患者が 人工肛門造設術の必要性と手術の効果を十分認 識でき, 安堵感を強く持てる一貫した患者教育 が重要であると考える。

ソーシャルサポートは, 患者の積極的生活姿 勢に影響している。Hubbardら ${ }^{23)}$ の研究は, ソ ーシャルサポートの認知の程度は健康への積極 的行動と強い正の関連を持っていることを示し た。患者が情緒的に強い支援をうけていると感 じると，熱中できることを生活に取り入れたり， くすぶっていないようにするという，術後の生 活に対する積極的生活姿勢を持つと考えられる。 Coburn ${ }^{24)}$ は, 家族のつながりの強さが健康へ の積極的行動を促す重要な指標であることを報 告している。積極的生活姿勢を持つには, 家族 から受けるソーシャルサポートの認知が重要で あると推測される。

積極的な生活姿勢をとることは, 健康的生活 
の実感につながり, 自己価值観を高めると考元

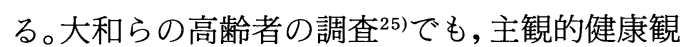
の高い者ほど自己価值観が高いことが報告され ている。健康的生活の実感と自己価值観の関連 は強いと考えられる。

\section{2.人工肛門造設患者のQOL構造モデルに影響 する要因}

人工肛門造設患者のQOL構造モデルに影響 する要因, 即ちQOLに関する患者の主観に影響 する要因は,いずれも家族が関係する3要因であ つた。

配偶者の存在は, 人工肛門の負担感を増加さ せている可能性があることが示唆されている。 患者の人工肛門の負担感に, 配偶者がどのよう に影響しているのかさらに検討するとともに， 患者の人工肛門の負担感を不用意に増加させる ような, 配偶者の言動を予防する家族教育が重 要であると考える。

装具交換を家族が全面的に行うことは, 患者 が感じるソーシャルサポートを低下させており， 家族との相互作用による肯定的な感情を生んで いないと推測される。患者の退院後の主観的評 価を向上させるためには，ストマケア指導時に， 家族に人工肛門装具交換を全てまかせきりにし てはならないと考える。

患者の性生活の満足度が, 生活の主観的評価 に影響していることが明らかになり, 虚血性心 疾患の患者でも指摘されるように ${ }^{1422622728)}$, 性 生活の満足は患者の主観的評価の観点からも重 要であると考える。

真田ら ${ }^{299}$ は, 自然排便者が洗腸施行者より自 己価值観が低く，不安が高いことを報告してい るが, 本研究では洗腸施行の程度, 人工肛門装 具の違いは, 生活の主観的評価に関連する因子 沙響していなかった。真田ら ${ }^{29}$ の研究対象者 の人工肛門保有年数は, 本研究の対象者より約 3年長く, 排便管理法の違いによる自己価值観の 差に関しては, 長期的な縦断的研究でさらに検 討する必要があると考える。

\section{VI.おわりに}

人工肛門造設患者の退院後の主観的評価を高
めていくために, 人工肛門造設患者のQOLモデ ルを作成し,さらにモデルを構成する因子に関 連する要因を明らかにした。

退院後, 患者と家族の間の相互作用をさらに 検討するとともに，家族に人工肛門装具交換を まかせきりにせず, 患者の人工肛門の負担感を 増加させない家族教育と性機能障害への援助が 重要であると考える。患者抢よび家族が術後の 主観的側面の変化を予測し対処できるよう, 生 活の主観的評価に関連する因子の構造を活用し た指導が必要であると考える。

\section{引用文献}

1) 高見沢恵美子, 佐藤禮子; 人工肛門造設患者 のQuality of Lifeに関する測定用具の作成 および信頼性と妥当性の検討, 日本看護科学 学会誌, 15(2), 41-48, 1995.

2) Burckhardt C.S.:The impact of arthritis on quality of life, Nursing Research, 34(1), 11-16, 1985.

3) Lazarus R.S.,Cohen J.B.:Study of stress and coping in aging, Paper presented at the 5th WHO Conference on Society, Stress, and Disease: Aging and Old Age, held in Stockholm, Sweeden, 1976.

4) Muhlenkamp A.F.,Sayles J.A.: Selfesteem, social support, and positive health practices, Nursing Research, 35 (6), 334 -338, 1986.

5) Linn L.S.,Lewis C.E.: Attitudes toward self-care among practicing physicians, Medical Care, 17, 183-190, 1979.

6) 宗像恒次;保健行動からみたセルフケア, 看 護研究，20(5)，428-437，1987.

7) 高見沢恵美子, 田原裕子, 宗像恒次; 四肢切 断者の退院後の自己価值観, 東京女子医大看 護短大紀要, 10, 75-80, 1989.

8) 宗像恒次 ; 健康のセルフケア行動, 看護技 術, 34 (9), 1012-1017, 1988.

9)渡辺正樹：Health Locus of Controlによる 保健行動予測の試み, 東京大学教育学部紀 要, 25, 299-307, 1985.

10)大村裕子, 西満正：自然排便法の排便状況か 
らみた洗腸法の適応についての検討, 日本ス トーマリハビリテーション学会誌, 3(2), 109-112,1987.

11)島田寛治, 赤井貞彦：オストメイトの社会復 帰と洗腸法, 日本ストーマリハビリテーショ ン学会誌，3(2)，95-99，1987.

12) 佐藤工キ子, 篠原富士子, 栅瀬信太郎他：長 期洗腸者 (8年-20年間)の実態調查一社会生 活における洗腸排便法の長所と短所一, 日本 ストーマリハビリテーション学会誌，2(2), 37-41, 1986.

13) 奥川直子: 人工肛門造設患者の精神的な適 応について, 東海ストーマリハビリテーシ ヨン会誌，8(1)，51-55，1988.

14) 黒田裕子：虚血性心疾患を持ちながら生活 する男性のクオリティー・オブ・ライフに関 する記述的研究 (その1), 看護研究，24(2), 163-182, 1991.

15)加藤知行, 平井孝, 安井健三, 他 : Quality of Lifeからみた直腸癌手術療法の進歩, 癌と化 学療法, 17(4)，741-746, 1990.

16) 今充, 森田隆幸, 藤田正弘, 他：人工肛門に 対するアンケート調査, 厚生省特定疾患消化 吸収障害調査研究班昭和 59 年度業績集, 26 , 2-296, 1985.

17) 北条慶一：直腸癌に対する拡大郭清の功罪, 外科治療， 57 (3)，298-301，1987.

18) Stanwyck D.J.: Self-esteem through the life span, Family and Community Health, 6(2), 11-28, 1983.

19) Lewis F.M.: Experienced personal control and quality of life in late-stage cancer patients, Nursing Research, 31, 113-119, 1982.

20) Padilla G.V., Presant C., et al.: Quality of life index for patients with cancer, Research in Nursing and Health, 6, 117126, 1983.

21) Young K.J., Longman A.J.: Quality of life and persons with melanoma: a pilot study, Cancer Nursing, 6, 219-225, 1983.

22) Earle J.R., Perricone P.J., et al.: Psychosocial adjustment of rheumatoid arthritis patients from two alternative treatment settings, Journal of Rheumatology, 6, 80-81, 1979.

23) Hubbard P., Muhlenkamp A.F.et al.: The relationship between social support and self-care practices, Nursing Research, 33, 266-270, 1984.

24) Coburn E., Pope C.R.: Socioeconomic status and preventive health behavior, Journal of Health and Social Behavior, 15(2), 67-77, 1974.

25) 大和三重他：日本の高齢者の自尊感情とそ の要因分析, 老年社会学, 12, 147-167, 1990

26) 黒田裕子：虚血性心疾患を持ちながら生活 する男性のクオリティー・オブ・ライフに関 する記述的研究 (その2), 看護研究, 25(2), 158-177, 1992.

27)黒田裕子：虚血性心疾患を持ちながら生活 する男性のクオリティー・オブ・ライフに関 する記述的研究 (その3), 看護研究, 25(3), 271-289, 1992.

28)黒田裕子：虚血性心疾患を持ちながら生活 する男性のクオリティー・オブ・ライフに関 する記述的研究 (その4), 看護研究, 25(4), 345-365, 1992.

29) 真田弘美, 川島和代, 津田光世, 他：排便方 法がオストメイトの精神的問題に及ぼす影 響, 日本ストーマリハビリテーション学会 誌，3(2)，101-108， 1987. 